\title{
EFFECTS OF EDUCATION, NUTRITION STATUS, TREATMENT COMPLIANCE, FAMILY INCOME, AND FAMILY SUPPORT, ON THE CURE OF TUBERCULOSIS IN MOJOKERTO, EAST JAVA
}

\author{
Puspitasari1 ${ }^{1,2)}$, Ambar Mudigdo3), Rita Benya Adriani4) \\ 1)Muhammadiyah University, Sidoarjo, East Java \\ 2)Masters Program in Public Health, Sebelas Maret University \\ 3)Faculty of Medicine, Sebelas Maret University \\ 4)School of Health Polytechnics, Surakarta
}

\begin{abstract}
Background: Tuberculosis is an important global public health issue. Countries around the world have committed to control the disease with various programs. However, the cure of Tuberculosis treatment in many countries is still low, which can hamper the success of Tuberculosis control program. Productivity of Tuberculosis patients continues to decrease that leads to socioeconomic burden. This study aimed to examine the effects of education, nutrition status, treatment compliance, family income, and family support, on the cure of Tuberculosis.
\end{abstract}

Subjects and Method: This was an observational analytic study with case control design. The study was conducted in Mojokerto, East Java, from April to May, 2017. A total sample of 108 Tuberculosis patients were selected for this study by fixed disease sampling. The sample consisted of 35 uncured cases of Tuberculosis and 73 cured cases of Tuberculosis. The dependent variable was cure of Tuberculosis. The independent variables were education, nutrition status, treatment compliance, family income, and family support. The data was collected by a set of questionnaire and analyzed using path analysis.

Results: Nutritional status $(b=1.31 ; 95 \% \mathrm{CI}=0.41$ to $2.22 ; \mathrm{p}=0.004)$ and treatment compliance $(\mathrm{b}=1.07 ; 95 \% \mathrm{CI}=0.17$ to $1.97 ; \mathrm{p}=0.019)$ directly and positively affect the cure of Tuberculosis. Nutritional status was affected by high education $(b=1.62 ; 95 \% \mathrm{CI}=0.62$ to $2.63 ; \mathrm{p}=0.002)$, family income $(\mathrm{b}=$ 1.66; $95 \% \mathrm{CI}=0.70$ to $2.62 ; \mathrm{p}=0.001)$, and strong family support $(\mathrm{b}=1.50$; $95 \% \mathrm{CI}=0.36$ to $2.63 ; \mathrm{p}=0.010)$. Treatment compliance was affected by high education $(b=0.84 ; 95 \% \mathrm{CI}=-0.14$ to $1.81 ; \mathrm{p}=0.093)$, family income $(\mathrm{b}=1.36$; $95 \% \mathrm{CI}=0.42$ to $2.30 ; \mathrm{p}=0.005)$, and strong family support $(\mathrm{b}=2.08 ; 95 \% \mathrm{CI}$ $=0.96$ to $3.19 ; \mathrm{p}<0.001)$.

Conclusion: Cure of Tuberculosis is directly affected by nutritional status and treatment compliance. Education, family support, and family income, indirectly affect cure of Tuberculosis.

Keywords: cure of Tuberculosis, education, nutrition status, family income, family support, treatment compliance

Correspondence: Puspitasari. Masters Program in Public Health, Sebelas Maret University, Jl. Ir. Sutami 36 A, Surakarta 57126, Central Java.

Email: puspita9o@yahoo.co.id. Mobile: +6281333060714. 